\title{
Development and Characterization of Metronidazole Loaded Microsponges for the Management of Diabetic Foot
}

\author{
Ponni Sujathan ${ }^{1}$, Umesh Kumar Sharma ${ }^{2}$ \\ ${ }^{1,2}$ Mar Dioscorus College of Pharmacy, Alathara, Sreekariyam, Trivandrum \\ Corresponding Author: Ponni Sujathan
}

\begin{abstract}
The objective of present work was formulation and evaluation of Metronidazole loaded microsponges for the management of diabetic foot ulcer via topical application and to reduce side effects. The microsponges were prepared by quasi-emulsion solvent diffusion method using different concentrations of Ethyl cellulose and Poly vinyl alcohol. The prepared microsponges were evaluated for particle size analysis, SEM, \% production yield, \% drug entrapment efficiency, in-vitro drug release studies, DSC and antimicrobial studies. FTIR studies shown that there was no interaction between drug and polymers. The optimum sustained release of drug around a period of $12 \mathrm{hrs}$ was shown by formulation F8. The $\mathrm{n}$ value of optimized formulation indicated that the drug release followed zero order kinetics. It was confirmed from the stability studies that the optimized formulation remained stable at $45 \pm 2$ ${ }^{\circ} \mathrm{C}$ and $70 \pm 5 \%$ relative humidity.
\end{abstract}

Keywords: Microsponges, Metronidazole, Diabetic Foot, Quasi-emulsion solvent diffusion, Sustained release, Scanning electron microscopy, Differential scanning calorimetry.

\section{INTRODUCTION}

The application of drug via skin to directly treat or cure the skin disorders is called topical delivery. Topical delivery systems are generally used for local skin infection or in places where other routes of the drug administration fail. These dosage forms are mostly applied to a small area anywhere in the body through ophthalmic, rectal, vaginal and skin as route. Skin is the largest and most accessible organ of human body Controlled drug delivery has wide and increased application in pharmaceutical industry. For topical delivery, drugs having lipophilic character are mostly suitable. These systems make the drug enter into the body and reach the area where it is needed. For providing local or systemic effects topical dosage forms are applied on to the skin.

As compared to the conventional system topical route favours safe and effective delivery of drugs with smaller doses. Drugs via skin reach the desired area in optimum concentration, thereby reduces the chance of side effects which leads to increased bioavailability and increased patient compliance.

Transdermal Drug Delivery System (TDDS) are defined as self-contained, discrete dosage forms which when applied to the intact skin, deliver the drug through the skin at a controlled rate to the systemic circulation. The dosage forms which are designed to deliver a therapeutically effective amount of drug across a patient's skin are called TDDS. The main objective of transdermal drug delivery system is to deliver drugs into systemic circulation through skin at predetermined rate with minimal inter and intra patient variation. The one which delivers the drug at a predetermined rate, for locally or systemically, for a specified period of time is referred to as controlled delivery. 
Ponni Sujathan et.al. Development and characterization of metronidazole loaded microsponges for the management of diabetic foot.

Controlled drug delivery systems provide the maintenance of drug levels within a desired range, fewer administrations, optimal use of the drug in question, and increased patient compliance. Currently many novel drug delivery systems are available such as organogel, emulgels, microsponges. hydrogels, liposomes, niosomes, etc.

In recent years, in order to modify and control the release behaviour of the drugs, a considerable priority has been given to develop novel Microsponge based drug delivery systems. Microsponges are porous, polymeric microspheres that are used mostly for topical use and have recently been used for oral administration. In this research work the Microsponges approach will be used to overcome the problems with the conventional topical / transdermal drug delivery systems. The polymeric delivery systems composed of porous microspheres which can enhance the stability, reduce side effects and modify drug release favourably are defined as microsponges. Mechanism of action highlights the importance of formulation. Microsponges are skilful to absorb skin secretion thereby they can reduce the moisture and prevent the infection and growth of bacteria at the site of action. Metronidazole ${ }^{[64][65]}$ is the drug of choice for anaerobic infection in diabetic foot ulcers (DFU) for a majority of clinicians. The present study is conducting to establish that the Metronidazole loaded microsponges are really making a difference in the management of DFU.

\section{MATERIALS \& METHODS}

Metronidazole (MTZ) was obtained as a gift sample from Balaji Drug Company, Gujarat. Poly Vinyl Alcohol (PVA) was purchased from Yarrow Chem, Mumbai. Ethyl cellulose and Dichloromethane were kindly given as a gift sample by Balaji drug company, Gujarat. All the chemicals used were of analytical grade and were used as received.

\section{Methods}

Preparation of Metronidazole loaded microsponges by Quasi-emulsion solvent diffusion method ${ }^{[42] .}$. The microsponges of respective composition as shown in table 1 were formulated using Ethyl cellulose as a polymer, Poly Vinyl Alcohol as a stabilizer.

Table: 1 Composition of Metronidazole loaded microsponges

\begin{tabular}{|l|l|l|l|l|l|l|l|l|}
\hline COMPONENTS & F1 & F2 & F3 & F4 & F5 & F6 & F7 & F8 \\
\hline Drug(g) & 1.5 & 1.5 & 1.5 & 1.5 & 1.5 & 1.5 & 1.5 & 1.5 \\
\hline Ethyl cellulose $(\mathrm{g})$ & 2 & 3 & 4 & 5 & 2 & 3 & 4 & 5 \\
\hline Dichloromethane $(\mathrm{ml})$ & 10 & 10 & 10 & 10 & 10 & 10 & 10 & 10 \\
\hline PVA $(\mathrm{g})$ & 0.3 & 0.3 & 0.3 & 0.3 & 0.7 & 0.7 & 0.7 & 0.7 \\
\hline
\end{tabular}

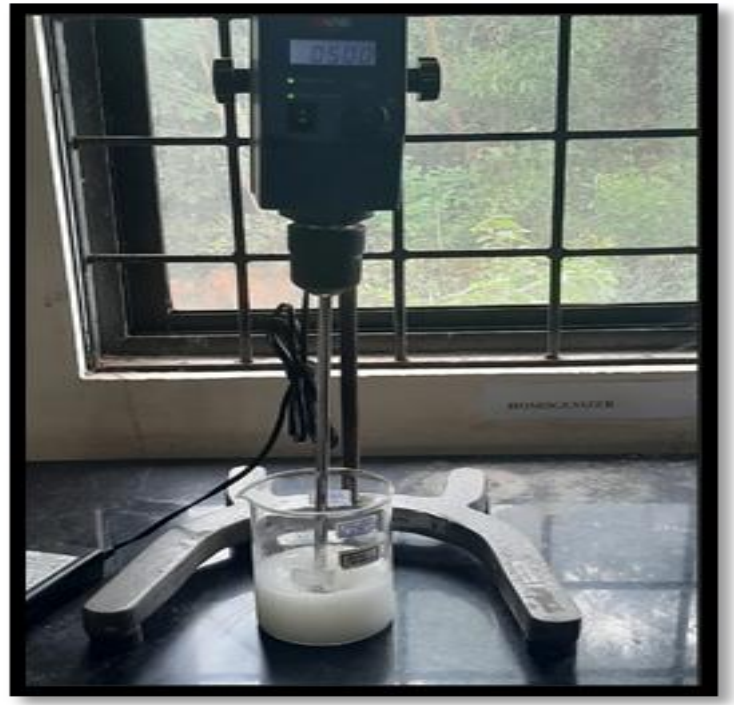

Fig 1: Preparation of microsponges by quasi emulsion solvent diffusion method
The microsponges loaded with Metronidazole were prepared by quasi emulsion solvent diffusion method. For that mainly two phases were considered, an internal phase and an external phase. The internal phase consists of accurately weighed amount of Metronidazole and Ethyl cellulose dissolved in Dichloromethane. The external phase consists of polyvinyl alcohol dissolved in warm water. PVA was used as an emulsifying or stabilizing agent. The internal phase was gradually added to external phase and stirred mechanically at 500 rpm for 2 hours at room temperature to remove the solvent Dichloromethane from 
Ponni Sujathan et.al. Development and characterization of metronidazole loaded microsponges for the management of diabetic foot.

the mixture. Microsponges formed were filtered and dried at room temperature and stored in a tightly closed container

\section{Evaluation of Metronidazole loaded microsponges \\ PREFORMULATION STUDIES}

Preformulation studies such as determination of organoleptic characteristics, solubility, melting point, determination of $K_{\max }$ and incompatibility study using FT-IR spectroscopy were conducted.

\section{Determination of organoleptic properties}

The physical appearance of the drug was observed and compared with the Pharmacopoeial specifications.

\section{Determination of melting point}

Melting point was determined by capillary method. Fine powder of Metronidazole was filled in glass capillary tube (previously sealed at one end). The capillary tube was inserted into the melting point apparatus and observed the temperature at which drug started to melt by using the thermometer which was already immersed into the liquid paraffin in the apparatus. The practically obtained melting point of Metronidazole was compared with that of theoretical melting point of the same.

\section{Solubility}

The solubility of Metronidazole was determined in various solvents such as water, Dichloromethane, Ethanol and Acetone. For those small increments of Metronidazole were added to $10 \mathrm{ml}$ of solvent (water, ethanol, dichloromethane, and acetone) in a $25 \mathrm{ml}$ stoppered flask with vigorous shaking. The solution was visually observed and if the solution was clear and no undissolved particles were observed, again another increment of Metronidazole was added and the procedure was continued until undissolved Metronidazole was found.

\section{Compatibility studies}

FT-IR Spectroscopy of Metronidazole

The pure drug was scanned from $4000-500 \mathrm{~cm}^{-1}$ in FT-IR spectrophotometer. The FT-IR spectrum of the obtained sample of drug and polymer were compared with the standard functional group frequencies.

\section{Compatibility between drug and polymer}

FT-IR spectroscopy was carried out to check the compatibility between drug and polymer. The compatibility between the drug, polymer were evaluated using FTIR peak matching method.

\section{PREPARATION OF STANDARD CALIBRATION CURVE}

\section{Preparation of standard calibration curve} of Metronidazole

Weighed accurately $50 \mathrm{mg}$ of pure Metronidazole \& made upto $50 \mathrm{ml}$ with 0.1 N HCL (stock solution A). Taken $10.0 \mathrm{ml}$ of the above solution \& diluted further to 50.0 $\mathrm{ml}$ with $0.1 \mathrm{~N}$ HCL (stock solution $\mathrm{B}$ ). Again taken $10 \mathrm{ml}$ of stock solution $\mathrm{B}$ and made upto $100 \mathrm{ml}$ with $0.1 \mathrm{~N} \mathrm{HCl}$. Pipetted out $0.2 \mathrm{ml}, 0.4 \mathrm{ml}, 0.6 \mathrm{ml}, 0.8 \mathrm{ml}, 1.0 \mathrm{mlof}$ the solution \& diluted to $10.0 \mathrm{ml}$ in separate $10 \mathrm{ml}$ volumetric flask to make $2,4,6,8,10 \mu \mathrm{g} / \mathrm{ml}$ concentration solutions. The absorbance was measured at $277 \mathrm{~nm}$ and standard calibration curve was plotted.

\section{CHARACTERIZATION OF METRONIDAZOLE LOADED MICROSPONGES}

\section{(1) Physical properties}

The prepared Metronidazole loaded microsponge formulations were inspected visually for their colour and appearance.

\section{(2) Particle size analysis}

Determination of the average particle size of Metronidazole loaded microsponges was determined with an optical microscope using a calibrated ocular and stage micrometer ${ }^{[42]}$. A minute quantity of microsponges was spread on a clean glass slide with a drop of liquid paraffin and a cover slip was placed on it. The average particle size was calculated by measuring 
Ponni Sujathan et.al. Development and characterization of metronidazole loaded microsponges for the management of diabetic foot.

100 particles of each batch using the equation:

$\mathrm{dav}=\sum \mathrm{nd} / \sum \mathrm{n}$

Where, dav is the average diameter of particles $(\mu \mathrm{m}), \mathrm{n}$ is number of particles per group, and $\mathrm{d}$ is the middle value $(\mu \mathrm{m})$.

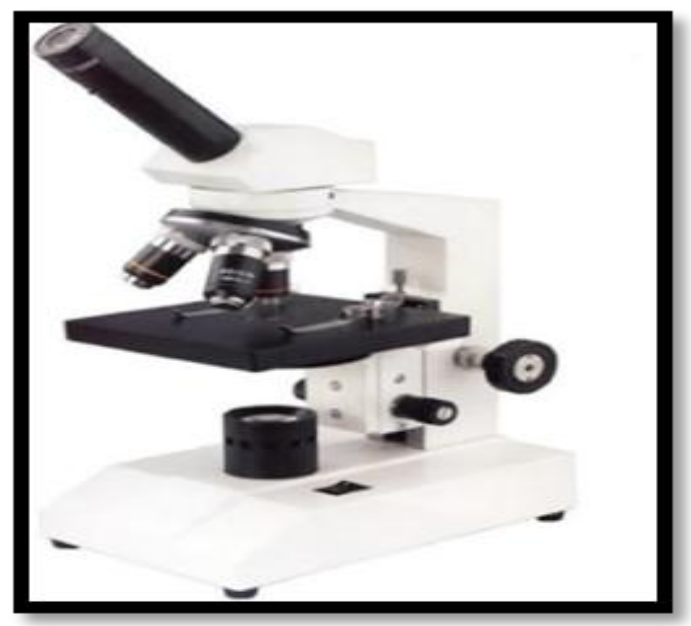

Fig 2: Particle size analysis of microsponges using optical microscope

\section{(3) Scanning electron microscopy}

For the evaluation of surface morphology of microsponges, the sample was analyzed in scanning electron microscope. The samples were randomly scanned and photomicrographs were taken at the acceleration voltage of $20 \mathrm{Kv}$.From the resulting image, average particle size was determined.

\section{(4) Production yield (\%)}

Percentage yield can be determined by calculating the initial weight of raw materials and the finally obtained weight of microsponges. Percentage yield can be calculated by using the formula ${ }^{[22]}$ :

Production yield $=$ (practical mass of microsponges)/(Theoretical

mass[drug\&polymer])*100

\section{(5) Drug content estimation and} Entrapment efficiency

Samples of drug loaded microsponges $(100 \mathrm{mg})$ were dissolved in $10 \mathrm{ml}$ phosphate buffer $\mathrm{pH} 7.4$ under sonication for $20 \mathrm{~min}$ at $25{ }^{\circ} \mathrm{C}$. The samples were filtered using $0.45 \mu \mathrm{m}$ membrane filter and analyzed for Metronidazole content spectrophotometrically using UV-VIS double beam spectrophotometer at $277 \mathrm{~nm}$. The actual drug content and entrapment efficiency were calculated as given below [22]:

Percentage drug content $=($ Actual drug content $) /($ Drug added in microsponges)*100 Percentge entrapment efficiency $=($ Actual drug in microsponges)/(Theoretical drug content)*100

\section{(6) Differential Scanning Calorimetry (DSC)}

DSC studies were carried out using Simultaneous Thermal Analyser STA 8000 instrument equipped with an intercooler. Indium and zinc standards were used to calibrate the DSC temperature and enthalpy scale. The samples were hermetically sealed in aluminum crucibles and heated at a constant rate of $10^{\circ} \mathrm{C} / \mathrm{min}$ over a temperature range of $25-300^{\circ} \mathrm{C}$. Inert atmosphere was maintained by purging Nitrogen gas at flow rate of $50 \mathrm{~mL} / \mathrm{min}$.

\section{(7) In- vitro drug release studies}

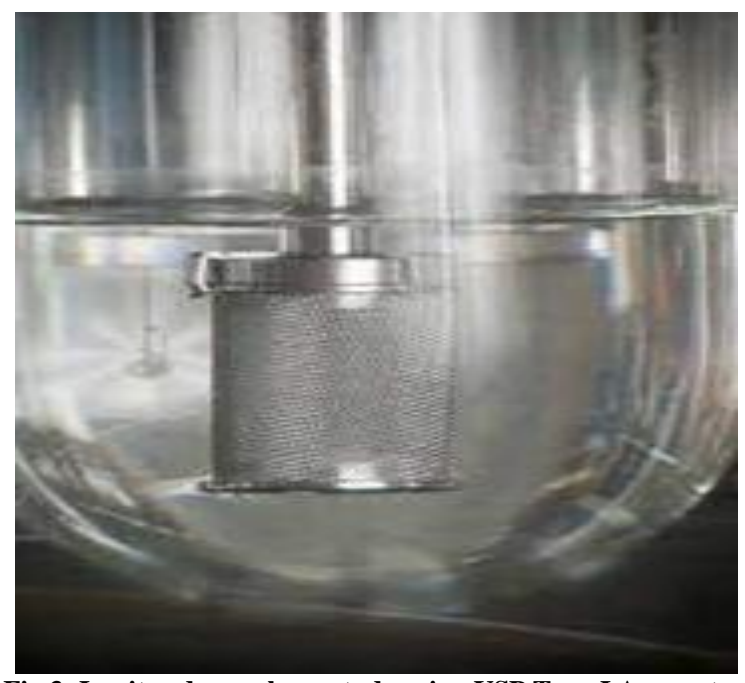

Fig 3: In-vitro drug release study using USP Type I Apparatus

In-vitro drug release study was carried out in USP dissolution test apparatus. A quantity of microsponges equivalent to $100 \mathrm{mg}$ of Metronidazole microsponges was kept in basket type apparatus and immersed in $900 \mathrm{ml}$ of phosphate buffer (pH 7.4) in $1000 \mathrm{ml}$ 
Ponni Sujathan et.al. Development and characterization of metronidazole loaded microsponges for the management of diabetic foot.

dissolution flask and temperature was maintained at $37 \pm 0.5^{\circ} \mathrm{C}$ throughout the study. At predetermined time intervals $2 \mathrm{ml}$ of samples was withdrawn by means of a syringe fitted with prefilter and same was replaced into the dissolution flask with phosphate buffer $\mathrm{pH}$ 7.4. The absorbance of sample was measured at $276 \mathrm{~nm}$ after required dilution with the fresh medium (pH.7.4). All the studies were conducted in triplicate.

\section{(9) Kinetics of In-vitro drug release}

The results obtained from in-vitro release studies were attempted to be fitted into various mathematical models as follows:

1. Cumulative percent drug released Vs Time (Zero order kinetics)

2. Log cumulative percent drug retained Vs. Time (First order kinetics

3. Cumulative percent released Vs Square root of Time (Higuchi model)

4. Log cumulative percent drug released Vs Log Time (Korsemeyer -Peppas model)

\section{Kinetic Models \\ Zero Order Kinetics}

It describes the system in which the drug release rate is independent of its concentration.

$\mathrm{Q}_{\mathrm{t}}=\mathrm{Q}_{0}+\mathrm{K}_{0 \mathrm{t}}$

Qt is the amount of drug released at time ' $t$ ' and

$\mathrm{K}_{0}$ is the zero- order release rate constant expressed in units of concentration/time. To study the release kinetics, cumulative amount of drug released Vs time. Zero order kinetics can be used to describe the drug dissolution of modified release pharmaceutical dosage forms, matrix tablets with low soluble drugs in coated forms, osmotic systems etc.

\section{First order Kinetics}

It describes the drug release from the systems in which the release rate is concentration dependent.

$\log \mathrm{Q}_{\mathrm{t}}=\log \mathrm{Q}_{0}+\mathrm{kt} / 2.303$
Where, $Q_{t}$ is the amount of drug released in time ' $\mathrm{t}$ '

$\mathrm{Q}_{0}$ is the initial amount of drug

$\mathrm{K}$ is the first order release constant

The data obtained from in vitro drug release studies were plotted as log cumulative percentage of drug remaining Vs time. First order kinetics can be used to describe the drug dissolution in pharmaceutical dosage forms such as those containing water-soluble drugs in porous matrices.

\section{Higuchi model}

It describes the fraction of drug release from a matrix is proportional to the square root of time. $\mathrm{Q}=\mathrm{K}_{2} \mathrm{t}^{1 / 2}$

$\mathrm{Q}$ is the percentage of drug released at time ' $t$ ' and

$\mathrm{K}_{2}$ is the Higuchi dissolution constant

The data obtained from in vitro drug release studies were plotted as percentage cumulative drug released Vs square root of time. Higuchi model can be used to describe the drug dissolution from modified release pharmaceutical dosage forms and matrix tablets with water soluble drugs and also to low water-soluble drugs incorporated to solid/semisolid polymer matrix.

\section{Korsmeyer-Peppas model}

It describes the drug release from the polymeric system in which release deviates from Fickian diffusion, as expressed in following equation.

$\mathrm{Q}=\mathrm{Kt}_{\mathrm{n}}$

$\mathrm{Q}$ is the percentage of drug released at time ' $t$ '

$\mathrm{K}$ is the release rate constant and

' $n$ ' is the diffusion release exponent indicative of the mechanism of drug release.

To study the release kinetics, the data obtained from in vitro drug release studies were plotted as log percentage cumulative drug release Vs time. NonFickian diffusion refers to combination of both diffusion and erosion-controlled rate release 
Ponni Sujathan et.al. Development and characterization of metronidazole loaded microsponges for the management of diabetic foot.

\section{(II)MICROBIAL STUDIES}

The organisms used in the study were Staphylococcus aureus and E.coli.

\section{Disk Diffusion Method}

An antimicrobial assay was performed by using the Kirby-Bauer disk diffusion agar plate method.Agar plate were prepared by pouring freshly prepared agar medium to the sterilized petridishes after autoclaving. The microbial suspension of Staphylococcus aureus and E.coli were applied onto the solidified agar by using sterile cotton swabs and allowed to dry for 10 minutes.Formulated drug loaded microsponges impregnated discs were aseptically transferred onto the inoculated agar plates and left to be inoculated for 2 days. The clear zones of inhibition around the test sample disc were shown for any indication of antimicrobial activity.All assays were carried out in triplicate.

\section{(III)STABILITY STUDY}

In any rational drug design or evaluation of dosage forms, the stability of the active component was a major criterion in determining their acceptance or rejection.For stability testing the formulation (F8) was stored at accelerated condition in aluminum foils for 3 months. The samples were withdrawn after end of 1st month, 2nd month and 3rd month. The samples were analyzed for its drug content and in vitro drug release.

\section{RESULTS AND DISCUSSION \\ Determination of organoleptic characters}

Table 2 :Organoleptic properties of drug sample

\begin{tabular}{|l|l|l|}
\hline SAMPLE & COLOUR & ODOUR \\
\hline Metronidazole & $\begin{array}{l}\text { White to yellowish crystalline } \\
\text { powder }\end{array}$ & Odourless \\
\hline
\end{tabular}

\section{Determination of melting point}

The experimental value of melting point of Metronidazole sample was in good agreement with the official value(159163),thus indicating the purity of sample

Table 3:Melting point of Metronidazole \begin{tabular}{|l|l} 
SAMPLE & MELTING POINT OBSERVED
\end{tabular}

\begin{tabular}{|l|l|}
\hline Metronidazole & $160^{\circ} \mathrm{C}$ \\
\hline
\end{tabular}

\section{Solubility studies}

Solubility of Metronidazole in various solvents like dichloromethane, acetone, ethanol and water were studied and found that it was freely soluble in dichloromethane and slightly soluble in acetone, ethanol and water.

\begin{tabular}{|c|c|c|c|}
\hline SOLVENTS & $\begin{array}{l}\text { AMOUNT OF } \\
\text { MTZ } \\
\text { DISSOLVED } \\
\text { IN } 10 \mathrm{ml} \\
\end{array}$ & $\begin{array}{l}\text { VALUES } \\
\text { IN mg/ml }\end{array}$ & Solubility \\
\hline Dichloromethane & 0.08 & 0.008 & $\begin{array}{l}\text { Freely } \\
\text { soluble }\end{array}$ \\
\hline Acetone & 0.06 & 0.006 & $\begin{array}{l}\text { Slightly } \\
\text { soluble }\end{array}$ \\
\hline Ethanol & 0.05 & 0.005 & $\begin{array}{l}\text { Slightly } \\
\text { soluble }\end{array}$ \\
\hline Water & 1 & 0.1 & $\begin{array}{l}\text { Slightly } \\
\text { soluble }\end{array}$ \\
\hline
\end{tabular}

\section{COMPATIBILITY STUDIES FTIR spectroscopy}

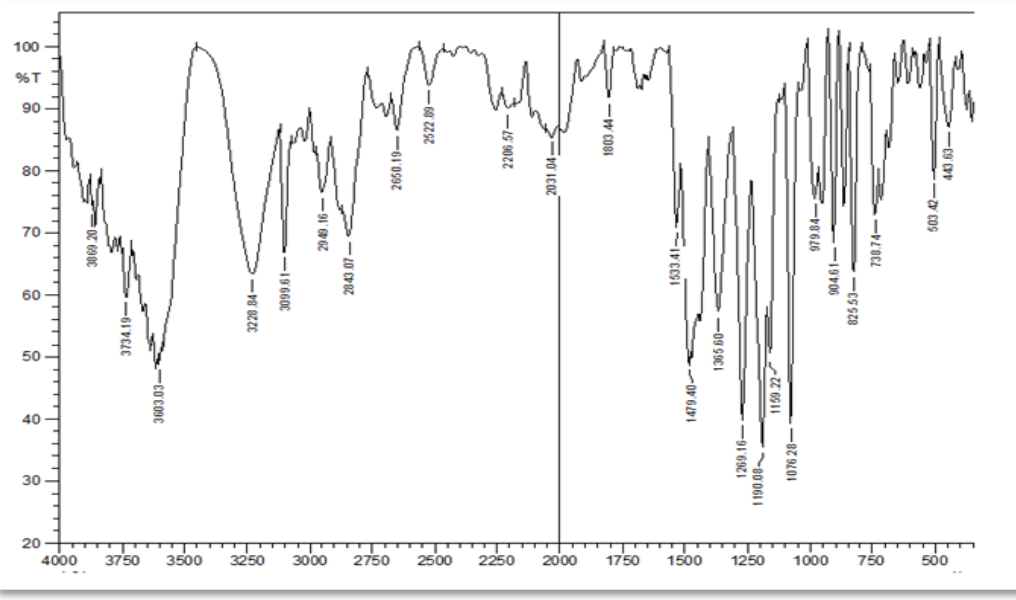


Ponni Sujathan et.al. Development and characterization of metronidazole loaded microsponges for the management of diabetic foot.

Figure 4:The FT-IR spectrum of Metronidazole

Table 5: IR frequencies of Metronidazole

\begin{tabular}{|l|l|l|}
\hline Functional groups & Standard IR peaks & Observed peaks \\
\hline $\mathrm{N}=\mathrm{O}$ & $1550-1350$ & 1533.41 \\
\hline$=\mathrm{C}-\mathrm{H}$ strecth & $3100-3000$ & 3099.61 \\
\hline$-\mathrm{CH}_{3}$ bending & $1475-1365$ & 1365.60 \\
\hline$-\mathrm{CH}_{2}$ bending & 1465 & 1479.40 \\
\hline$-\mathrm{C}=\mathrm{C}$ alkene & $1600 \& 1465$ & 1533.41 \\
\hline
\end{tabular}

The FTIR spectrum of Metronidazole is shown in Figure 4, which complies with standard functional group frequencies.

\section{Compatibility between drug and polymer}

The FTIR spectrum of combination of Metronidazole with excipients are shown in figure 5.

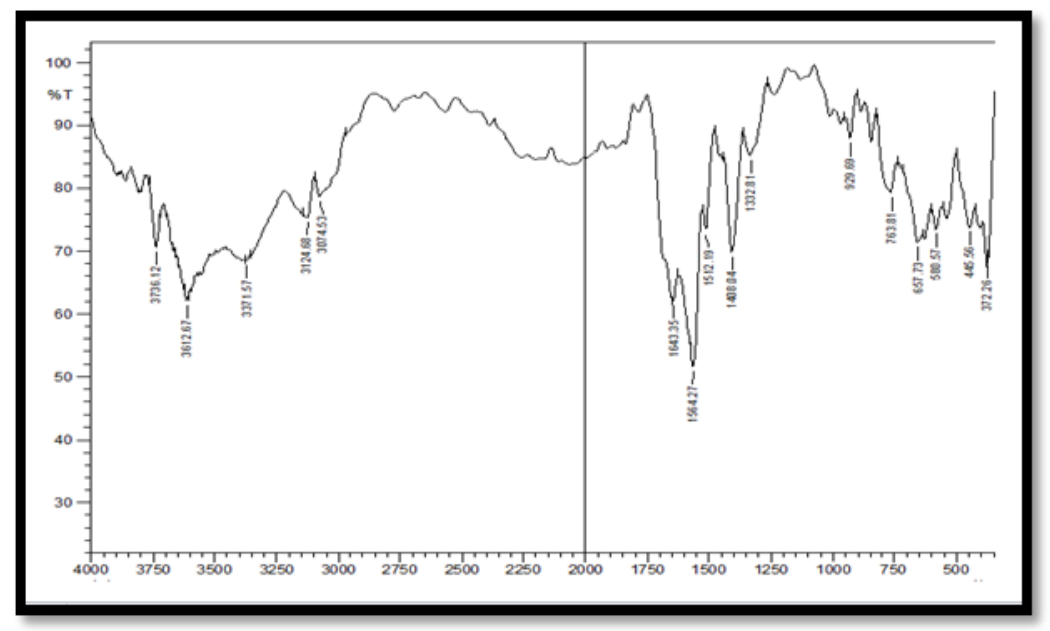

Figure 5 :FTIR spectrum of physical mixture of drug \& polymers

Table 6: IR frequencies of Metrnodizaole with other excipients

\begin{tabular}{|l|l|l|l|}
\hline $\begin{array}{l}\text { Functional } \\
\text { groups }\end{array}$ & $\begin{array}{l}\text { Standard IR } \\
\text { peaks }\end{array}$ & $\begin{array}{l}\text { MTZ } \\
\text { observed } \\
\text { peaks }\end{array}$ & $\begin{array}{l}\text { Observed IR } \\
\text { peaks }\end{array}$ \\
\hline $\mathrm{N}=\mathrm{O}$ & $1550-1350$ & 1533.41 & 1512.19 \\
\hline $\begin{array}{l}=\mathrm{C}-\mathrm{H} \\
\text { stretch }\end{array}$ & $3100-3000$ & 3099.61 & 3074.53 \\
\hline $\begin{array}{l}-\mathrm{CH}_{3} \\
\text { bending }\end{array}$ & $1475-1365$ & 1365.60 & 1332.81 \\
\hline $\begin{array}{l}-\mathrm{CH}_{2} \\
\text { bending }\end{array}$ & 1465 & 1479.40 & 1408.04 \\
\hline $\mathrm{C}=\mathrm{C}$ alkene & $1600 \& 1475$ & 1533.41 & 1408.04 \\
\hline
\end{tabular}

After the compatibility study of Metrnonidazole with excipients, the IR spectra of pure drug and drug-excipient physical mixture were analyzed.The peaks analyzed in the Table 6 indicate that,most characteristic frequencies of functional group of Metronidazole which are $\mathrm{N}=\mathrm{O},=\mathrm{C}$ $\mathrm{H}$ stretch , $-\mathrm{CH}_{3}$ bending and $\mathrm{C}=\mathrm{C}$ were found unchanged.This shows that the Metronidazole remained unaffected by the excipients used.No new complexes were observed as well.So it could be concluded that there was no interaction between drug and excipients used.

\section{PREPARATION OF STANDARD \\ CALIBRATION CURVE OF METRONIDAZOLE}

Standard calibration curve of Metrnonidazole was determined in Hydrochloric acid by measuring the absorbance of the standard solutions at 277 $\mathrm{nm}$ using double beam UV spectrophotometer.

Table7: Absorbance of Metronidazole standard solutions at $277 \mathbf{~ n m}$

\begin{tabular}{|l|l|}
\hline $\begin{array}{l}\text { Concentration } \\
(\boldsymbol{\mu g} / \mathbf{m l})\end{array}$ & $\begin{array}{l}\text { Absorbance } \\
(\mathbf{n m})\end{array}$ \\
\hline 2 & 0.082 \\
\hline 4 & 0.175 \\
\hline 6 & 0.257 \\
\hline 8 & 0.342 \\
\hline 10 & 0.481 \\
\hline
\end{tabular}

Figure 6 shows standard calibration curve of Metronidazole with slope and regression coefficient and intercept of 0.9986 and 0.0434 respectively. It was found that the solutions show linearity $(\mathrm{R} 2=0.9986)$ in the range of 2-6 $\mu \mathrm{g} / \mathrm{ml}$ at $K \max 276 \mathrm{~nm}$ and obeys Beer Lambert's law. 
Ponni Sujathan et.al. Development and characterization of metronidazole loaded microsponges for the management of diabetic foot.

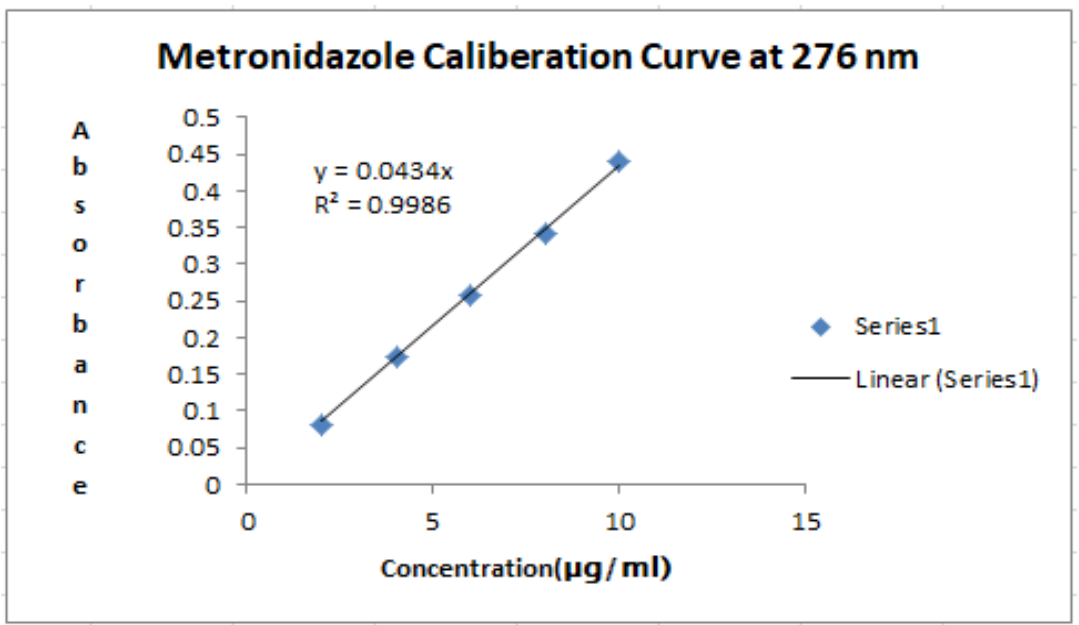

Figure 6 :Standard calibration curve of Metronidazole at $276 \mathrm{~nm}$

\section{FORMULATION OF \\ METRONIDAZOLE LOADED MICROSPONGES}

Metronidazole loaded microsponges were prepared by quasi-emulsion solvent diffusion method at varying concentrations of polymer and emulsifire as shown in table 1 .

\section{CHARACTERISATION AND EVALUATION OF METRONIDAZOLE LOADED MICROSPONGES Physical properties}

Table 8: Colour and appearance of prepared microsponge formulations

\begin{tabular}{|c|c|c|}
\hline $\begin{array}{l}\text { FORMULATION } \\
\text { CODE }\end{array}$ & COLOUR & APPEARANCE \\
\hline F1 & White & Spherical,free flowing \\
\hline F2 & White & Spherical,free flowing \\
\hline F3 & White & Spherical,free flowing \\
\hline F4 & White & Spherical,free flowing \\
\hline F5 & White & Spherical,free flowing \\
\hline F6 & White & Spherical,free flowing \\
\hline F7 & White & Spherical, free flowing \\
\hline F8 & White & Spherical, free flowing \\
\hline
\end{tabular}

All the prepared Metronidazole micropsonge formulations were white in colour,free-flowing in nature and had rigid spherical structure. The concentration of emulsifying agent or external phase has a major role to play in the formation of microsponges.Minimum concentration of external phase is required.Insufficient concentration of emulsifying agent produces unstable microsponges.

\section{Particle size analysis}

The particle size of microsponges was determined using an optical microscope.The mean particle size of Metronidazole loaded microsponges ranged from 11.51 to $20.82 \mu \mathrm{m}$ as shown in Table 9.It was found that,when concentration of polymer increases, the mean particle size of the microsponge also increases. This may be attributed to the hugher viscosity of the internal phase, thus increasing the chances of formation of bigger particles and faster diffusion of the solvent.

Table 9:Mean particle size of MTZ microsponges

\begin{tabular}{|c|c|}
\hline FORMULATION & MEAN PARTICLE SIZE $(\boldsymbol{\mu m})$ \\
\hline F1 & $11.51 \mu \mathrm{m}$ \\
\hline F2 & $13.32 \mu \mathrm{m}$ \\
\hline F3 & $15.64 \mu \mathrm{m}$ \\
\hline F4 & $17.52 \mu \mathrm{m}$ \\
\hline F5 & $16.79 \mu \mathrm{m}$ \\
\hline F6 & $17.83 \mu \mathrm{m}$ \\
\hline F7 & $19.7 \mu \mathrm{m}$ \\
\hline F8 & $20.82 \mu \mathrm{m}$ \\
\hline
\end{tabular}

\section{Scanning electron microscopy}

The surface morphology of the optimized microsponge formulationF8 was investigated by scanning electron microscopy (SEM). The SEM image is shown in figure 8.The SEM images showed that the surface of prepared microsponges was spherical in shape and uniform in size and its surface was porous in nature. The pores were induced by the diffusion of the volatile solvent(dichloromethane) from the surface of the microparticles. No intact crystal of drug was seen visually. Based on 
Ponni Sujathan et.al. Development and characterization of metronidazole loaded microsponges for the management of diabetic foot.

SEM studies, the mean particle size of microsponges was found to be $20 \mu \mathrm{m}$.

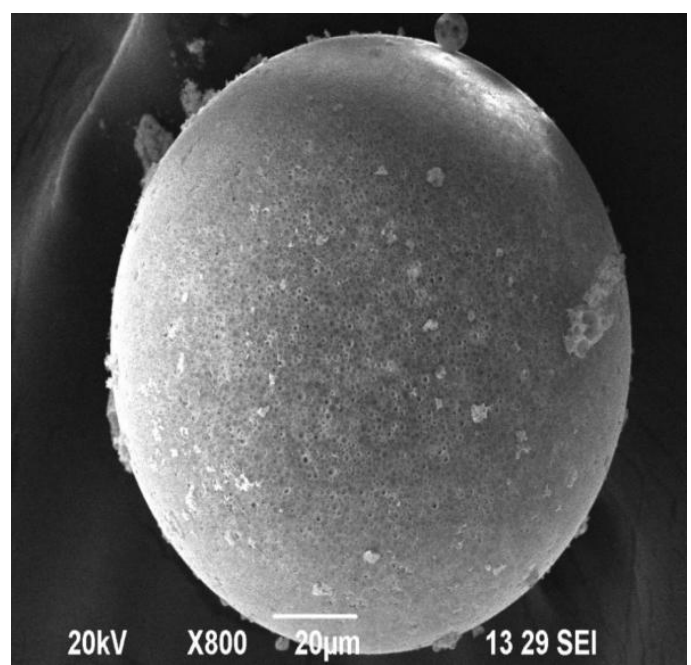

Fig 8: SEM images of MTZ loaded microsponges

\section{Production yield $(\%)$}

The production yield of Metronidazole loaded microsponges was found to be in the range of $44.7-94 \%$ as reported in Table. When the concentration of polymer added was increased the production yield of microsponges was also found to be increased.This may be due to the higher amount of polymer,thus resulting in an increase in total mass of the microsponges.

Table 10: Percentage production yield of microsponge formulations

\begin{tabular}{|c|c|}
\hline FORMULATION & PRODUCTION YIELD(\%) mean \pm SD \\
\hline F1 & $44.7 \%$ \\
\hline F2 & $49.37 \%$ \\
\hline F3 & $46 \%$ \\
\hline F4 & $51.05 \%$ \\
\hline F5 & $89 \%$ \\
\hline F6 & $92 \%$ \\
\hline F8 & $90 \%$ \\
\hline
\end{tabular}

\section{Drug content (\%)}

The percentage drug content of drug loaded microsponges was found to be in the range of $90-98.6 \%$ as shown in table 5.11. From that it was found that the drug remained in entrapped form in microsponges and was uniformly distributed.
Table 11:Percentage drug content of prepared microsponges

\begin{tabular}{|c|c|}
\hline FORMULATION & DRUG CONTENT(\%) mean \pm SD \\
\hline F1 & $90.6 \%$ \\
\hline F2 & $92 \%$ \\
\hline F3 & $93.3 \%$ \\
\hline F 4 & $94.6 \%$ \\
\hline F5 & $90 \%$ \\
\hline F6 & $93 \%$ \\
\hline F $~$ & $97 \%$ \\
\hline
\end{tabular}

\section{Drug entrapment efficiency}

The percentage drug entrapment efficiency of Metronidazole loaded microsponge formulations ranged from 60 $98.6 \%$ as shown in Table 12.The results of drug entrapment efficiency $(\%)$ showed that with increase in polymer concentration ,the drug entrapment efficiency(\%) also increased.The increase in drug entrapment efficiency with increase in polymer concentration may be due to the sufficient amount of polymer being available for the drug to be entrapped.

Table12: Percentage drug entrapment efficiency of microsponge formulations

\begin{tabular}{|c|c|}
\hline FORMULATION & $\begin{array}{c}\text { DRUG ENTRAPMENT } \\
\text { EFFICIENCY(\%) }\end{array}$ \\
\hline F1 & 60 \\
\hline F2 & 62 \\
\hline F3 & 82 \\
\hline F4 & 86 \\
\hline F5 & 70 \\
\hline F6 & 93.33 \\
\hline F7 & 72 \\
\hline F8 & 98.66 \\
\hline
\end{tabular}

\section{Differential scanning calorimetry}

In DSC studies, dispersed in polymer showed the same thermal behaviour as a pure compound.In the thermogram,the endothermic peak was observed at $160^{\circ} \mathrm{C}$ which does not correspond to the melting point of the pure drug.During formulation of microsponges the drug was entrapped inside the microsponges and was not available for showing any exothermic peak.Hence,no endothermic peak near to the melting point of the drug was observed confirming the entrapment of drug in microsponges. This indicates that the physical properties of Metronidazole were altered during formulation of microsponges using Ethyl cellulose. 
Ponni Sujathan et.al. Development and characterization of metronidazole loaded microsponges for the management of diabetic foot.

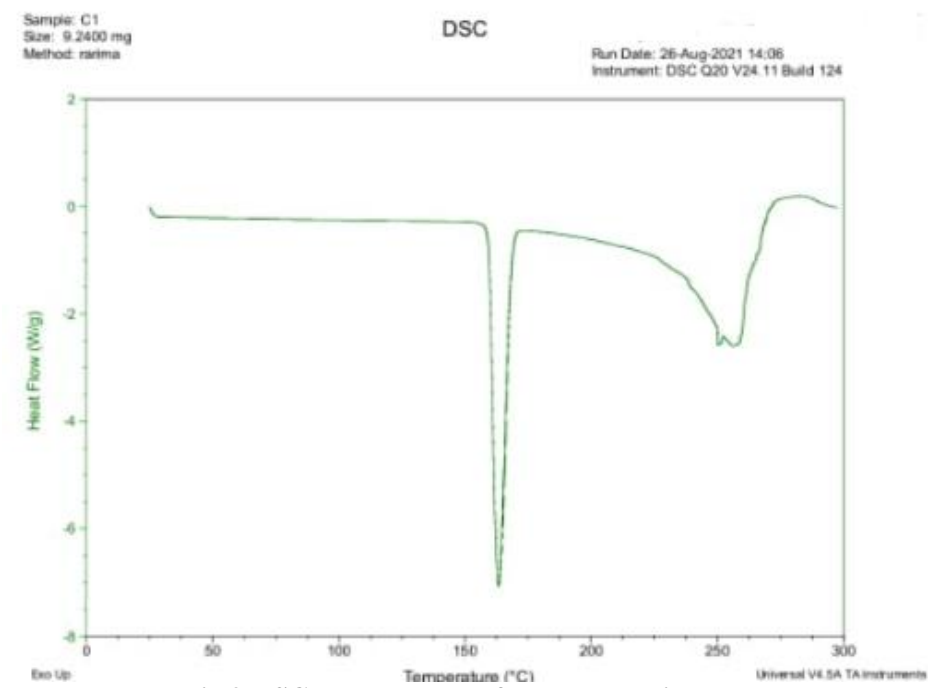

Fig 9:DSC Thermogram of pure Metronidazole

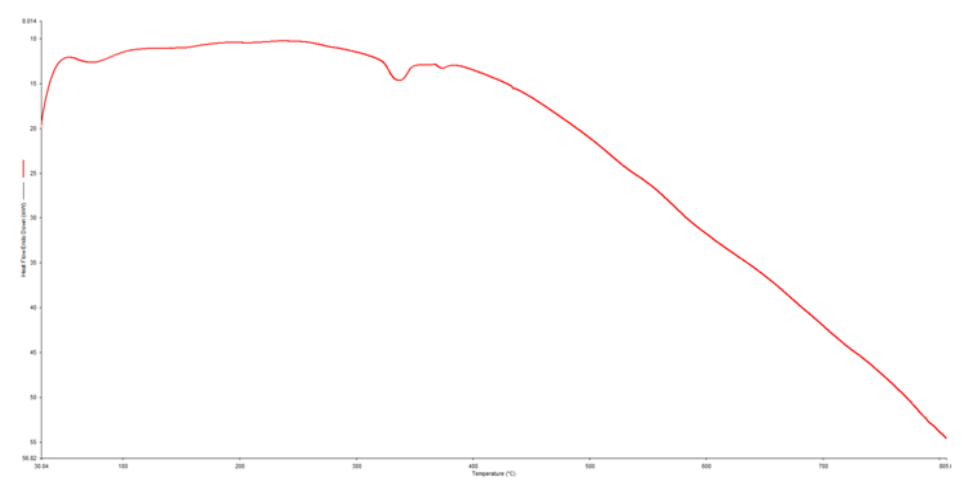

Fig 10:DSC Thermogram of optimized formulation F8

\section{Invitro drug release study} $12 \mathrm{hrs}$

The in-vitro drug release studies were carried out using USP Type I apparatus for

\begin{tabular}{|c|c|c|c|c|c|c|c|c|}
\hline $\begin{array}{l}\text { TIME } \\
\text { (hrs) }\end{array}$ & $\begin{array}{l}\text { F1 } \\
\text { (\% CDR })\end{array}$ & $\begin{array}{l}\text { F2 } \\
\text { (\% CDR })\end{array}$ & $\begin{array}{l}\text { F3 } \\
\text { (\% CDR })\end{array}$ & $\begin{array}{l}\text { F4 } \\
\text { (\% CDR })\end{array}$ & $\begin{array}{l}\text { F5 } \\
\text { (\% CDR) }\end{array}$ & $\begin{array}{l}\text { F6 } \\
\text { (\% CDR })\end{array}$ & $\begin{array}{l}\text { F7 } \\
\text { (\% CDR })\end{array}$ & $\begin{array}{l}\text { F8 } \\
\text { (\% CDR })\end{array}$ \\
\hline 0 & 0 & 0 & 0 & 0 & 0 & 0 & 0 & 0 \\
\hline 0.25 & 19.92 & 17.64 & 19.92 & 17.23 & 19.51 & 19.92 & 18.89 & 19.51 \\
\hline 1 & 26.158 & 23.25 & 26.15 & 24.70 & 22.83 & 24.49 & 24.70 & 21.79 \\
\hline 2 & 33.00 & 31.97 & 33.00 & 28.23 & 28.23 & 28.23 & 27.81 & 25.74 \\
\hline 3 & 38.40 & 38.61 & 38.40 & 35.08 & 32.80 & 32.80 & 32.38 & 30.10 \\
\hline 4 & 42.76 & 42.76 & 42.76 & 45.88 & 40.27 & 40.27 & 42.97 & 43.38 \\
\hline 5 & 48.99 & 51.07 & 48.99 & 53.14 & 43.59 & 43.59 & 46.29 & 47.12 \\
\hline 6 & 59.16 & 59.37 & 59.16 & 61.03 & 51.69 & 51.69 & 54.80 & 53.14 \\
\hline 7 & 67.67 & 63.73 & 67.67 & 63.11 & 59.99 & 59.99 & 59.58 & 61.03 \\
\hline 8 & 75.77 & 68.09 & 74.52 & 71.62 & 64.97 & 65.39 & 66.22 & 66.43 \\
\hline 9 & 80.75 & 79.92 & 80.75 & 79.92 & 79.71 & 76.60 & 71.00 & 76.39 \\
\hline 10 & 85.53 & 84.70 & 85.53 & 84.70 & 83.87 & 86.15 & 85.53 & 88.43 \\
\hline 11 & 87.19 & 88.43 & 87.19 & 87.19 & 88.43 & 88.43 & 90.51 & 95.91 \\
\hline 12 & 92.38 & 93.83 & 94.04 & 94.87 & 95.08 & 96.53 & 97.98 & 99.85 \\
\hline
\end{tabular}

From the in-vitro drug release data of MTZ microsponges, it was observed that the percentage cumulative drug release of
MTZ decreased as the concentration of ethyl cellulose was increased.The increase in the ethyl cellulose concentration leads to the 
Ponni Sujathan et.al. Development and characterization of metronidazole loaded microsponges for the management of diabetic foot.

increased density of polymer matrix of microsponges which results in an increased diffusion path length. This may decrease the overall drug release from the polymer matrix.The optimum controlled release of drug was shown by formulationF8.F8 released $99.85 \%$ of the drug in 12
hrs.Among all the formuations ,the least \% cumulative drug release of $92.38 \%$ was shown by F3.F3 contains microsponges formed using low concentration of emulsifying agent compared to F8. Therefore F1to F4 showed a decrease in drug release compared to $\mathrm{F} 8$.

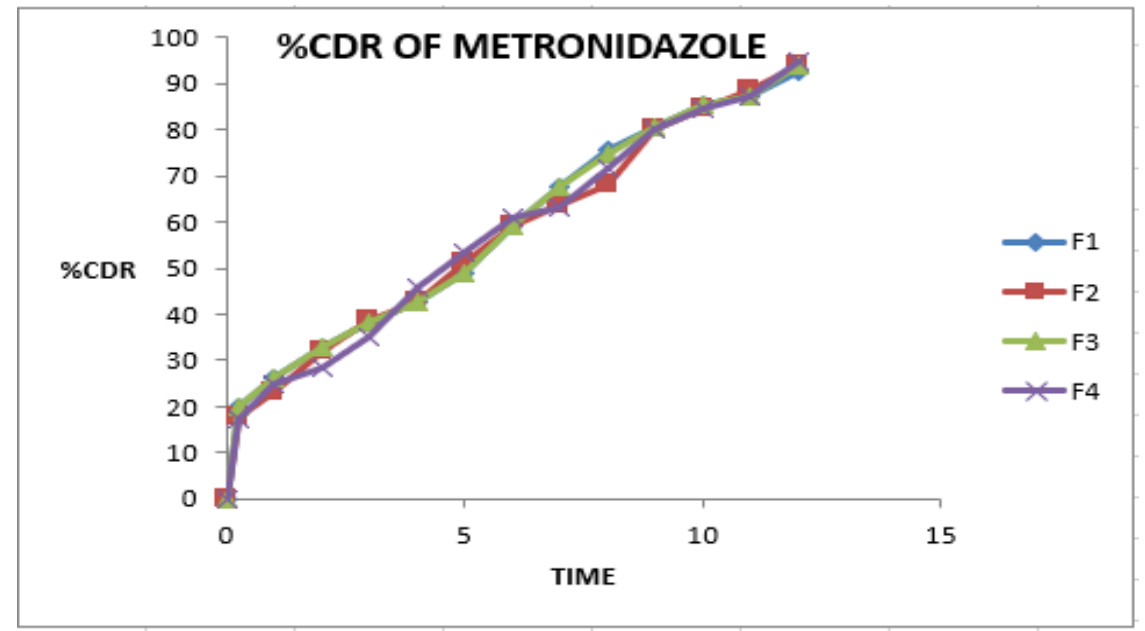

Fig11:Comparison of percentage cumulative drug release profile of formulations F1-F4.

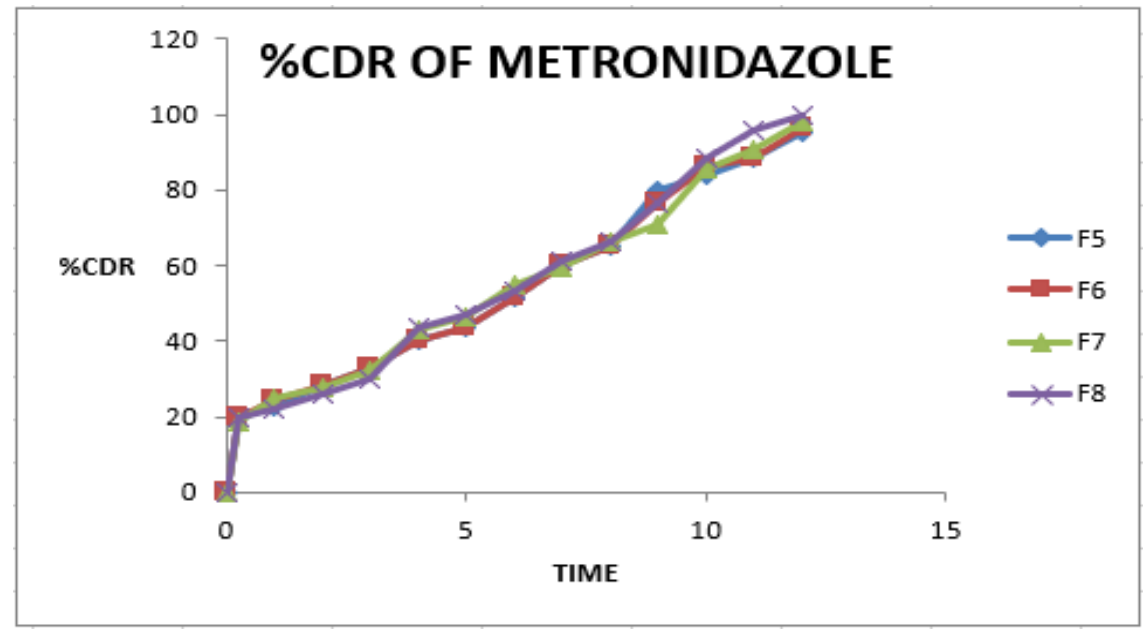

Fig 12Comparison of percentage cumulative drug release profile of formulations F5-F8

\section{Kinetics of In vitro drug release}

Table 14: Kinetic study of MTZ microsponges

\begin{tabular}{|c|c|c|c|c|c|}
\hline \multirow[t]{3}{*}{ Formulation } & \multicolumn{5}{|c|}{ Drug release kinetics } \\
\hline & \multirow{2}{*}{$\begin{array}{l}\text { Zero order } \\
\mathbf{R}^{2}\end{array}$} & \multirow{2}{*}{$\begin{array}{l}\text { First order } \\
\mathbf{R}^{2}\end{array}$} & \multirow{2}{*}{$\begin{array}{l}\text { Higuchi } \\
\mathbf{R}^{2}\end{array}$} & \multicolumn{2}{|c|}{ Peppas } \\
\hline & & & & $\mathbf{R}^{2}$ & $\mathbf{n}$ \\
\hline F1 & 0.9602 & 0.957 & 0.978 & 0.037 & 0.202 \\
\hline $\mathrm{F} 2$ & 0.973 & 0.926 & 0.987 & 0.630 & 0.575 \\
\hline F3 & 0.966 & 0.936 & 0.981 & 0.639 & 0.581 \\
\hline $\mathrm{F} 4$ & 0.972 & 0.917 & 0.985 & 0.625 & 0.59 \\
\hline F5 & 0.977 & 0.874 & 0.986 & 0.555 & 0.571 \\
\hline F6 & 0.976 & 0.834 & 0.985 & 0.516 & 0.595 \\
\hline F7 & 0.976 & 0.772 & 0.986 & 0.469 & 0.637 \\
\hline F8 & 0.980 & 0.628 & 0.987 & 0.347 & 0.664 \\
\hline
\end{tabular}

The invitro drug release data of all the MTZ microsponges was subjected to goodness of fit test by linear regression analysis according to zero order and first order kinetic equations,Higuchi's and Korsmeyer-Peppas models to ascertain the mechanism of drug 
Ponni Sujathan et.al. Development and characterization of metronidazole loaded microsponges for the management of diabetic foot.

release.The results of linear regression analysis including regression coefficients are summarized in Table 14

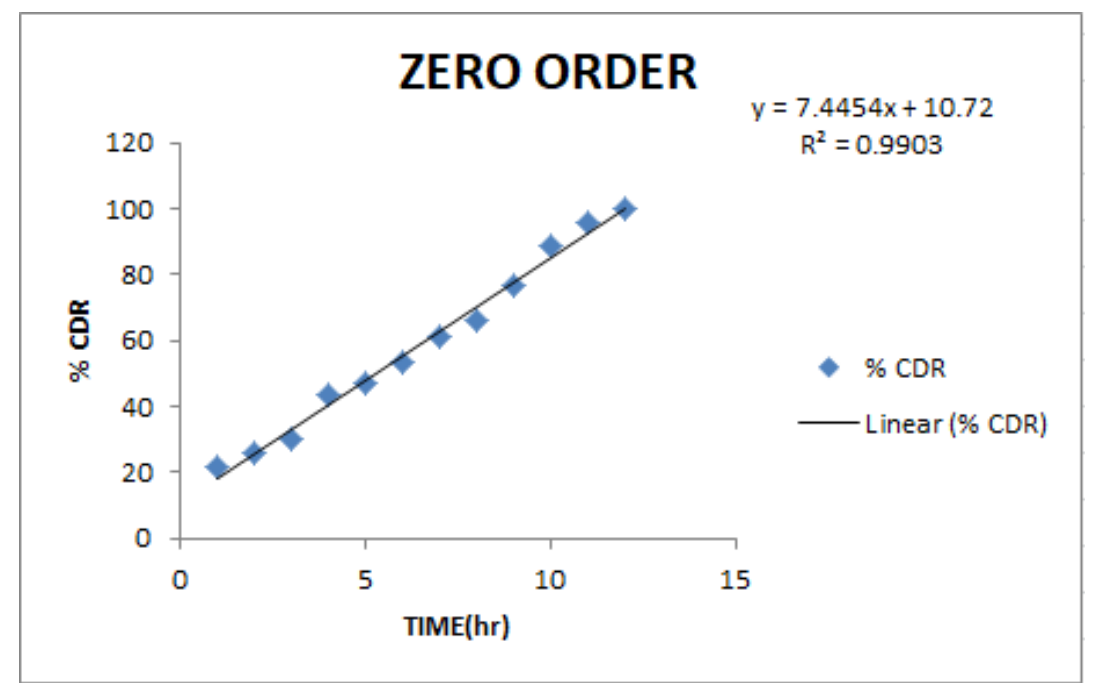

Fig13:Zero order release kinetics profile of optimised formulation $F 8$

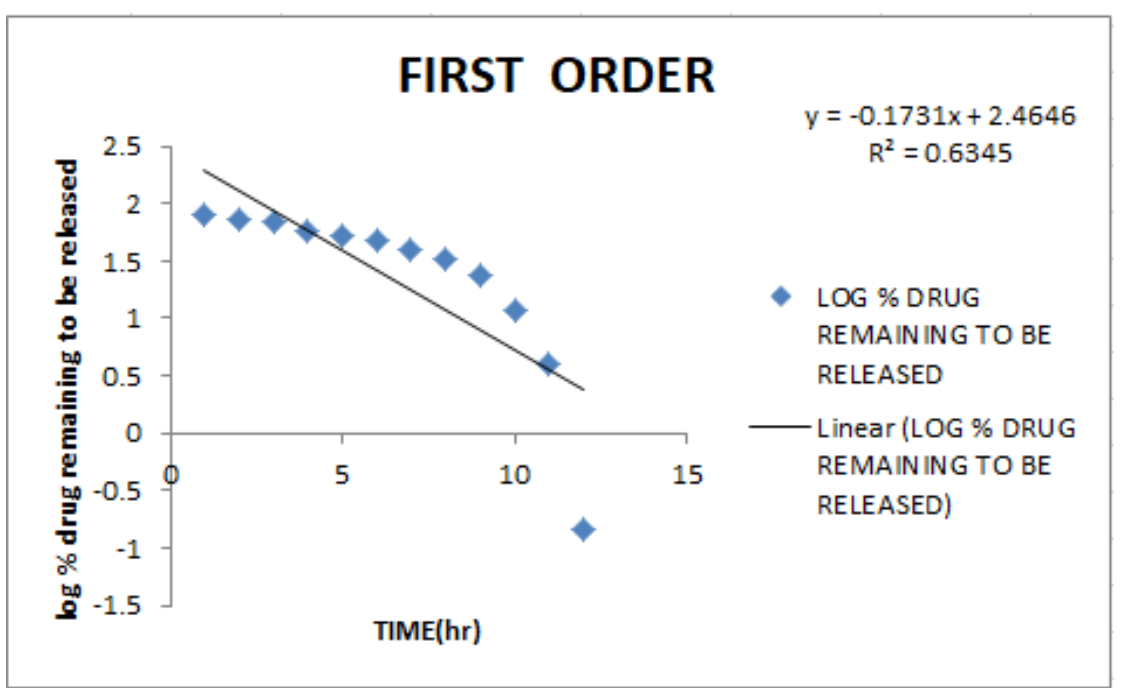

Fig 14:First order release kinetics profile of optimised formulation F8

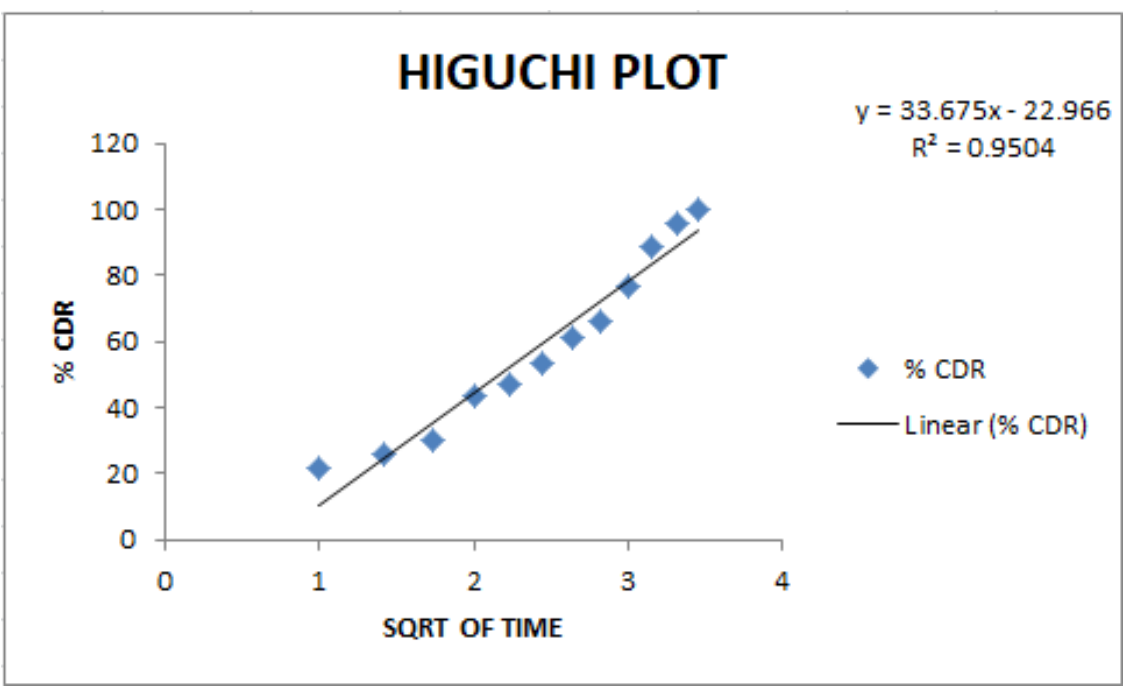

Fig15:Higuchi release kinetics profile of optimized formulation F8 
Ponni Sujathan et.al. Development and characterization of metronidazole loaded microsponges for the management of diabetic foot.

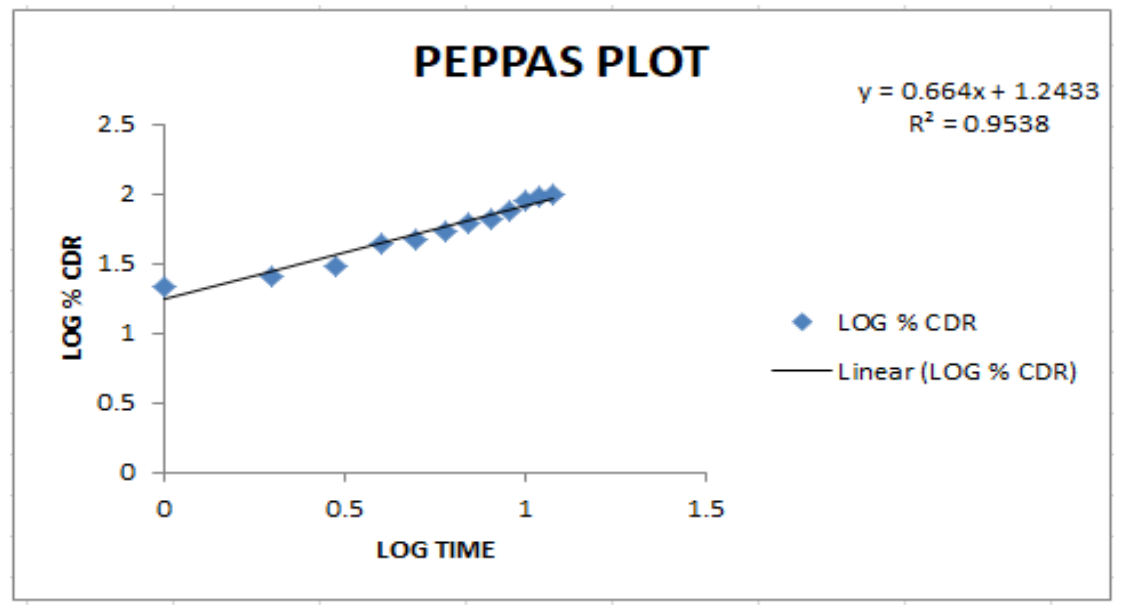

Fig16:Peppas release kinetics profile of optimized formulation F8

From the above data it was found that all formulations $\mathrm{F} 1, \mathrm{~F} 2, \mathrm{~F} 3, \mathrm{~F} 4, \mathrm{~F} 5, \mathrm{~F} 6, \mathrm{~F} 7$ and $\mathrm{F} 8$ followed zero order kinetics with $\mathrm{R}^{2}$ values $\quad 0.96,0.97,0.96,0.97,0.97,0.97,0.98$ respectively.To ascertain the drug release mechanism,the In-vitro drug release data were also subjected to Korsmeyer-Peppas plot.The 'n' values of optimised microsponge formulation $\mathrm{F} 8(\mathrm{n}=0.98)$ suggests that the drug was released by zero order kinetics with anomalous(non-Fickian) release.Non-Fickian diffusion refers to combination of both diffusion and erosion controlled rate release..All other formulations also followed case II nonFickian mechanism.

Evaluation of antibacterial activity by disk diffusion method

The antimicrobial activity of optimized microsponge formulation F8 was carried out using Kirby-Bauer disk diffusion agar plate method. Staphylococcus aureus and E.coli were used as test organism.From the evaluation of bacterial activity,it was observed that the optimized formulation showed a clear zone of inhibition around the sample disc.

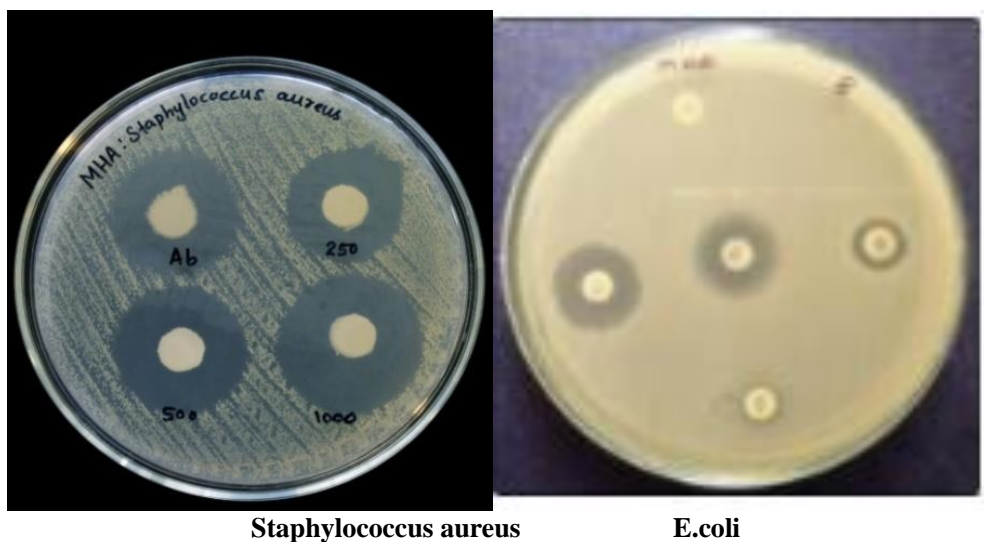

\section{Stability studies}

The formulation F8 was observed after specified period stability studies as per ICH guidelines .The formulations was monitored for drug content and In-Vitro drug released profile and results were represented in Table 15 and percentage drug released profile was shown.
Table 15: Data of stability studies of formulation (F8)

\begin{tabular}{|c|c|c|c|}
\hline Characteristics & $\begin{array}{l}\text { Before } \\
\text { stabilty } \\
\text { studies }\end{array}$ & $\begin{array}{l}\text { After } \\
\text { stability } \\
\text { studies } \\
\text { (Day 45) }\end{array}$ & $\begin{array}{l}\text { After } \\
\text { stability } \\
\text { studies } \\
\text { (Day 90) } \\
\end{array}$ \\
\hline $\begin{array}{l}\text { Physical } \\
\text { appearance }\end{array}$ & $\begin{array}{l}\text { Spherical,free } \\
\text { flowing }\end{array}$ & No change & No change \\
\hline $\begin{array}{l}\text { Drug } \\
\text { content }(\%)\end{array}$ & 98.6 & 98.59 & 98.48 \\
\hline $\begin{array}{ll}\begin{array}{l}\text { In-vitro } \\
\text { released }\end{array} & \text { drug } \\
\end{array}$ & 99.85 & 99.79 & 99.69 \\
\hline
\end{tabular}


Ponni Sujathan et.al. Development and characterization of metronidazole loaded microsponges for the management of diabetic foot.

The results obtained from the stability studies showed that the optimized formulation $\mathrm{F} 8$ remain stable at $40^{\circ} \mathrm{C}$. There was no change in appearnace. From the stability studies it was confirmed that the optimized formulation of MTZ microsponges are stable at $40^{\circ} \mathrm{C}$ and $75 \%$ relative humidity.

\section{CONCLUSION}

Metronidazole loaded microsponges were prepared by quasi-emulsion solvent diffusion method at varying concentrations of polymer and emulsifier. Characterization studies were conducted and found they complied with the standards. Standard calibration curve of Metronidazole was plotted. The Kmax was observed at 276nm and found it obeys Beer Lambert's law. Drug polymer compatibility studies were conducted and found there was no incompatibility. Microsponges were evaluated for physical properties, production yield, particle size, SEM, DSC, drug content and entrapment efficiency, In vitro drug release studies stability and microbial studies. All the prepared MTZ loaded microsponges were white in colour, free flowing in nature and had a rigid structure. The percentage production yield of microsponge formulations was found to be in the range of 44-94\%. The highest production yield was given by F8 and it was found that $\%$ production yield increased with increasing polymer concentration. The mean particle size of all microsponge formulations were found in the range of 11.51-20.82 $\mu \mathrm{m}$. Based on SEM studies the mean particle size of microsponges was found to be $20 \mu \mathrm{m}$.From DSC studies, it was confirmed that drug was entrapped into microsponges. The drug entrapment efficiency (\%) of MTZ loaded microsponge formulations ranged from 60-98\% and showed that with increase in polymer concentration, the drug entrapment efficiency (\%) was also increased. The \% drug content of drug loaded microsponges was found to be in the range of $90-98 \%$. From the in vitro drug release studies, it was found that Formulation F8 was more efficient to give sustained drug release which released $99.85 \%$ drug at the end of 12 hrs. The optimum sustained release of drug around a period of $12 \mathrm{hrs}$ was shown by formulation F8. All formulations followed zero order kinetics. The ' $n$ ' value of optimized formulation F8 indicated that the drug release follows zero order kinetics and Non Fickian diffusion. From the evaluation of bacterial activity, it was observed that the optimized formulation showed a clear zone of inhibition around the sample disc. It was confirmed from the stability studies that the optimized formulation remained stable at $40^{\circ} \mathrm{C}$ and $75 \%$ relative humidity. Based on the above evaluation studies, it could be concluded that, the formulation F8was considered as optimized formulation and it was safe and effective for topical use for Diabetic Foot Ulcer and shows a sustained release without side effects.

\section{ACKNOWLEDGEMENTS}

Firstly, I would like to give all the credit, gratitude and thanks to the great God for making each and every task related to my dissertation possible and successful and also his infinite blessings and love always guided me throughout my studies and life. It is a great pleasure to acknowledge my deepest thanks and gratitude to my esteemed guide, Prof.Dr. Umesh Kumar Sharma, Principal\& HOD, Mar Dioscorus College of Pharmacy, Alathara, Sreekariyam, Trivandrum for his guidance, support, constructive criticism and never diminishing encouragement during the progress of my thesis work. Without his critical advice and deep-rooted knowledge, this work would not have been a reality. It is a great honour to work under his supervision. I take this opportunity to acknowledge my sincere thanks to Karunya Institute of Nanosciences \& Technology, Coimbatore, University of Kerala, Kariavattom, Trivandrum and Biogenix Research Centre, Poojapura for their technical support for carrying out SEM, DSC and Antimicrobial study. I also thank Smt. Bessy, associate professor, 
Ponni Sujathan et.al. Development and characterization of metronidazole loaded microsponges for the management of diabetic foot.

Women's College, Vazhuthacaud for providing facilities for carrying out FTIR.

\section{Conflict of Interest: None}

\section{Source of Funding: None}

\section{Ethical Approval: Approved}

\section{REFERENCES}

1. Brahmankar DM, Sunil B Jaiswal. Biopharmaceutics and Pharmcokinectics A Treatise.2009., 1(2): 399-400.

2. Vyas SP, Khar RK. Controlled drug delivery- Concepts and advances. 2002., 4(1):156-157

3. Namrata Jadhav, et al .Microsponge Delivery System: An updated review, current status and future prospects. Journal of Scientific and Innovative Research. 2013; 2 (6): 1097-1110.

4. Sandhyarani Sagavkar R, Shrinivas Mohite $\mathrm{K}$ Innovative And Novel Strategy,Microsponges Drug Delivery System . International Journal of Universal Pharmacy and Bio Sciences 2014; 3(4):7992.

5. Charde MS, Ghanawat PB, Welankiwar AS, Kumar J, Chakole RD. Microsponge A Novel New Drug Delivery System: A Review. International Journal of Advances in Pharmaceutics. 2013; 2 (6) :63-70.

6. Kapoor D, Vyas RB, Lad C, Patel M, Tyagi BL. A Review On Microsponge Drug Delivery System . Journal of Drug Delivery \& Therapeutics. 2014; 4(5): 29-35 .

7. Shyam Sunder Mandava, Vedavathi Thavva. Novel Approach: Microsponge Drug Delivery System. International Journal of Pharmaceutical Science and Research, 2012; 3(4): 967-980.

8. Yerram Chandramouli ,et al. Microsponges: A Novel Drug Delivery System For Controlled Delivery Of Topical Drugs. International Journal of Pharmaceutical Research \& Analysis . 2010; 2 (2): 79-86 .

9. Manisha K Tile and AY Pawar. Microsponges: A novel strategy for Drug delivery.International Journal of Pure and Applied Biosciences.2015; 3 (1): 224-235.

10. Hibah Aldawsari, Shaimaa Badr-Eldin. Microsponges as promising vehicle for drug delivery and targeting: Preparation, characterization and applications. African Journal of Pharmacy and Pharmacology.2014; 7(17): 873-881.

11. Saurabh Kumar, LK Tyagi, Dashrath Singh. Microsponge Delivery System (MDS): A Unique Technology For Delivery Of Active Ingredients . International Journal of Pharmaceutical Science and Research. 2011; Vol. 2(12): 3069-3080.

12. Ravi R, SK Senthilkumar, S Parthiban .Microsponges Drug Delivery System: A Review. International Journal of Pharmacy Review \& Research. 2013; 3(1):6-11.

13. Hamid Hussain, Divya Juyal, Archana Dhyani . Microsponges: An Overview . International Journal of Drug Delivery Technology. 2014; 4(4): 58-66.

14. Viral Shaha, Hitesh Jain, Jethva Krishna, Pramit Patel. Microsponge drug delivery: A review. International Journal Research Pharmaceutical Science. 2010;1(2): 212218.

15. Ankaj Kaundal, Rohit Bhatia, Amit Sharma, Pankaj Sukrial. A Review On Microsponges Drug Delivery System. International Journal of Advanced Pharmaceutics. 2014;4(3) :177-181.

16. Vikas Jain, Ranjith Singh. Development and characterization of Eudragit RS 100 loaded microsponges and its colonic delivery using natural polysaccharides. Acta Poloniae Pharmaceutica- Drug research .2010;67(4):407-415.

17. Vikas Jain, Ranjith Singh. Dicyclomine loaded Eudragit - based Microsponge with Potential for Colonic Delivery:Preparation and Characterization. Tropical Journal of Pharmaceutical Research. 2010;9(1):6772.

18. Anilkumar J,Shinde,Manoj B,Paithane, Sujata Sawant. Development and Evaluation of Fenoprofen Microsponges and its Colonic Delivery using Natural Polysaccharides. American Journal of Pharmaceutical Sciences and Nanotechnology. 2014; 1(1) : 27-42.

19. Riyaz Ali M Osmani, Nagesh Aloor, Bharathi Thaware, Parthasarrathi Kulkarni. Microsponges based drug delivery system for augmented gastroparesis therapy: Formulation development and evaluation.Asian Journal of Pharmaceutical Sciences.2015;10(5): 1-24.

20. Karthika R, Elango K, Ramesh Kumar K, Rahul K. Formulation and Evaluation of 
Ponni Sujathan et.al. Development and characterization of metronidazole loaded microsponges for the management of diabetic foot.

Lornoxicam Microsponge Tablets for the treatment of Arthrits. International Journal of Pharmaceutical Innovations. 2013; 3(2) : 29-40.

21. Sonali, Rahul Pratap Singh, Sunil Kumar Prajapati. Formulation and evaluation of Prednisolone loaded microsponges for colon drug delivery: Invitro and Pharmacokinectic study. International Journal of Pharmaceutical Sciences and Research. 2014; 5(5) : 1994-2005.

22. Rashmi Sareen, Kavita Nath, Nitin Jain, KL Dhar. Curcumin Loaded Microsponges for Colon Targetin in Inflammatory Bowel Disease: Fabrication, Optimization, and Invitro and Pharmacodynamic Evaluation. BioMed Research International. 20146(3): 1-7.

23. Ramani Gade, Anitha Makineni, Aparna.A, Krishna Keerthi B, TEGK Murthy, Chandu Babu Rao, Sreekanth. Design and development of Hydroxyzine hydrochloride controlled release tablets based on Microsponge technologyBentham Science . 2013; 1(1): 172-184.

24. Shah Harsh, Karishma Patel, UMU padhyay. Formulation and evaluation of controlled release colon targeted microsponge of Aceclofenac. The Pharma Innovation Journal. 2014; 3(10):81-87.

25. Riyaz Ali M Osmani, Nagesh Aloor, Bharathi Thaware, Parthasarrathi Kulkarni. Microsponges based novel drug delivery system for augmented Arthritis therapy. Saudi Pharmaceutical Journal. 2015: 1-11.

26. John I D'souza, Harinath N More.Topical anti- inflammatory gels of Fluocinolone Acetonide entrapped in Eudragit based microsponge delivery system. Research $J$ Pharma and Tech. 2008; 1 (4) : 502-506.

27. Markand Mehta, Amish Panchal, Viral H Shah, Umesh Upadhyay. Formulation and In- vitro evaluation of controlled release microsponge gel for topical delivery of Clotrimazole. International Journal of Advanced Pharmaceutics. 2012; 2(2): 93101.

28. Hamid Hussain, Archana Dhyani, Divya Juyal, Abhishek Bahuguna. Formulation and evaluation of gel- loaded microsponges of Diclofenac sodium for topical delivery. The Pharma Innovation Journal. 2014; 3(10): 5863.
29. Makwana Rajeshree, Patel Harsha, Patel Vishnu. Photostability enhancement of Micanazole nitrate by microsponge formulation. International Journal of Current Trends in Pharmaceutical Research. 2014;2(3): 437-458.

30. Ramadevi Bhimavarapu, Karuna Priya Chitra, Karunkiran P, Raviteja G, Meharagavendra Y, Sundaramma.S. Itraconazole loaded microsponges- A novel carrier system. International Journal of Inventions in Pharmaceutical sciences. 2015; 3(1): 953-957.

31. Mahanjan Aniruddha G, Jagtap Leena S, Chaudhari Atul L, Swami Sima P, Mali Prabha R. Formulation and evaluation of microsponge drug delivery system using Indomethacin. International Research Journal of Pharmacy. 2011; 2(10):64-69.

32. Ravi R, Senthil Kumar SK, Parthiban S . Formulation and evaluation of the microsponges gel for an anti acne agent for the treatment of acne. Indian Journal of Pharmaceutical Science and Research. 2013; 3(1): 32-38.

33. Mohan Kumar V, Veena N M, Manjula BP. Formulation and evaluation of microsponges for topical drug delivery of Mupirocin. International Journal of Pharm Tech Research. 2013;5(3): 1434-1440.

34. Swetha A, Gopal Rao M, Venkata Ramana K, Niyaz Basha B and Koti Reddy V. Formulation and in- vitro evaluation of Etodolac entrapped in microsponge based drug delivery system. International Journal of Pharmacy. 2011 ; 1(2) : 73-90.

35. Yadav P , Nanda S. Development and evaluation of some microsponge loaded medicated topical formulations of acyclovir. International Journal of Pharmaceutical Sciences and Research . 2014;5(4): 13951410.

36. Atmaram P Pawar, Aditya P Gholap , Ashwin B Kuchekar, C Bothiraja , Ashwin J Mali . Formulation and Evaluation of Optimized Oxybenzone Microsponge Gel for Topical Delivery. Hindawi Publishing Corporation Journal of Drug Delivery. 2015;3(8) 1-9.

37. Chainesh Shah, Dhiren Shah. Design and optimization of fluconazole microsponges Containing ethyl cellulose for topical delivery system using Quality by design 
Ponni Sujathan et.al. Development and characterization of metronidazole loaded microsponges for the management of diabetic foot.

approach. An International Journal of Pharmaceutical Science 2014;5(3): 95-133.

38. Jaya Raja Kumar, Selvadurai Muralidharan, Sanggetha Ramasamy.Microsponges Enriched Gel (MEGs): A Novel Strategy for Opthalmic Drug Delivery System Containing Ketotifen. International Journal of Pharmaceutical Science and Research. 2013;5(4): $97-102$.

39. Roaa Nief, Ahmed Hussein. Preparation and Evaluation of Meloxicam Microsponges as Transdermal Delivery System .Iraqi Journal of Pharmaceutical Sciences.2014; 23(3) :63-74.

40. Ahmed Abbas Hussein. Preparation and Evaluation of Oral Microsponge Drug Delivery System of Ketoconazole. American Journal of Pharmaceutical Sciences. 2014; 14(1) :1-8.

41. Kirti A Londhe, Sheetal B Gondkar, Ravindranath B Saudagar. Preparation and Characterization of Diclofenac Sodium Loaded Microsponges for Capsules. American journal of PharmTech and Research. 2014; 4(6): 408413.

42. Ravi $R$ and Senthil Kumar SK. Standardization Of Process Parameters Involved Erythromycin Microsponges By Quasi Emulsion Solvent Diffusion Method . International Journal of Pharmaceutical Development \& Technology. 2013;3 (1) : 28-34.

43. Rama raoet al. Formulation and in vitro evaluation of ethyl cellulose microspheres containing zidovudine. Journal of Microencapsulation.2005; 22(8): p.863876.

44. Chowdary et al . Ethylcellulose microspheres of Glipizide; characterization, in vitro and in vivoevaluation. Ind. J. Pharm.2004 66(4) : 1-33.

45. Amitava Ghoshet al . Development, evaluation and method selection for the preparation of lamivudine microspheres.International journal of drug development and research.2011; 5(3):277284

46. Embil K, Nacht S. The Microsponge ${ }^{\circledR}$ delivery system (MDS): A topical delivery system with reduced irritancy incorporating multiple triggering mechanims for the release of actives. $J$ Microencapsul. 1996;13:575-88.
47. D'souza JI, et al .Design and Evaluation of Benzoyl Peroxide Microsponges to Enhance Therapeutic Efficacy in Acne Treatment.Pubmed.2007;38(8):834-840.

48. D'souza JI. In-vitro Antibacterial and Skin Irritation Studies of Microsponges of Benzoyl Peroxide. Indian Drugs. 2001;38:23.

49. Kawashima $\mathrm{Y}$, Niwa T, Takeuchi H, Hino T, Itoh Y. Control of Prolonged Drug Release and Compression Properties of Ibuprofen Microsponges with Acrylic Polymer, Eudragit RS, by changing their Intraparticle Density. Chem Pharm Bull. 1992;40:196-201.

50. Aritomi H, Yamasaki Y, Yamada K, Honda H, Koshi M. Development of sustained release formulation of chlorpheniramine maleate using powder coated microsponges prepared by dry impact blending method. $J$ Pharm Sci Tech. 1996;56:49-56.

51. OrluM , Cevher E, Araman A. Design and evaluation of colon specific drug delivery system containing flurbiprofen microsponges. Int $J$ Pharm. 2006;3(18): 103-17.

52. Khopade AJ, Jain S, Jain NK. The Microsponge. East Pharm. 1996;39:49-53.

53. Nacht S, Kantz M. The microsponge: A novel topical programmable delivery system. Top Drug Deliv Syst. 1992;42:299325.

54. Won R. Method for delivering an active ingredient by controlled time release utilizing a novel delivery vehicle which can be prepared by a process utilizing the active ingredient as a porogen. Patent No 4690825 US: 1987.

55. Comoğlu T, Gönül N, Baykara T. Preparation and in vitro evaluation of modified release ketoprofen microsponge. Farmaco. 2003;58:101-6.

56. Nawal A and Mohammad S: Formulation and in-vitro evaluation of piroxicam microsponge as a tablet. International Journal of Pharmacy and Pharmaceutical Sciences, 2016; 8(2): 104-11.

57. Mantry S, Das S and Das S: Microsponge as novel strategy of drug delivery system. Universal Journal of Pharmaceutical Science and Research 2015; 1(1): 32-38.

58. Sumpio BE, Lee T, Blume PA. Vascular evaluation and arterial reconstruction of the 
Ponni Sujathan et.al. Development and characterization of metronidazole loaded microsponges for the management of diabetic foot.

diabetic foot. Clin Podiatr Med Surg. 2003;20:689-708.

59. Oliveira N, Rosa P, Borges L, Dias E, Oliveira F, Cássio I. Treatment of diabetic foot complications with hyperbaric oxygen therapy: a retrospective experience. Foot Ankle Surg. 2014;20:140-143.

60. Baker LL, Chambers R, DeMuth SK, Villar F. Effects of electrical stimulation on wound healing in patients with diabetic ulcers. Diabetes Care. 1997;20:405-412.

61. Devraj., et al. oral dosage form proposed for the attainment of timed release drug delivery of Metronidazole, Journal of Pharmacy Research, 2010;3(7) 211-219.

62. Bhatt.J H., et al. Controlled release of Metronidazole mucoadhesive microspheres, International Journal of Pharma Tech Research, 2009; 2(4), 2575-2595.
63. Akanksha garud., et al. Metronidazole microcpasules with a coat consisting of alginate and natural cationic polymers, Journal of Pharmacy Research, 2010, 2712996.

64. http://www.druginfosys.com/Drug.aspx?dru gCode $=479 \&$ drugName $=$ metronidazole $\&$ ty $\mathrm{pe}=1$

65. Indian Pharmacopoeia, Ministry of Health and Welfare Department,Ghaziabad, India. The Indian Pharmacopoeia Commission. 2014; Vol 2: 1543-45

How to cite this article: Sujathan P, Sharma UK. Development and characterization of metronidazole loaded microsponges for the management of diabetic foot. International Journal of Research and Review. 2021; 8(10): 440-457. DOI: https://doi.org/10.52403/ijrr. 20211059 